\title{
Ritual and Presentation in Early Buddhist Religious Architecture
}

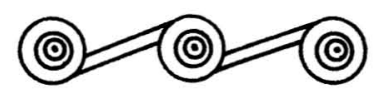

LARS FOGELIN

From the First CENTURY B.C. THROUGH THE SECOND CENTURY A.D., South Asian Buddhists focused much of their ritual and worship upon stone or brick mounds, stupas, containing the relics of the Buddha. Some stupas were found in large, open-air complexes that were the focus of pilgrimage by the Buddhist laity. Other smaller stupas were located within the worship halls, chaityas, of Buddhist monasteries carved into the sides of cliffs. In each case, the people who created these temples had to decide how to present the stupa for worship. In both cases, the designers had to accommodate the highly individualistic nature of Buddhist worship while attempting to provide mechanisms to foster group cohesion within the developing Buddhist community. Monks designed their own ritual spaces with the goal of allowing for the mediation of worship by ritual specialists. In contrast, stupa complexes frequented by the laity were designed in a way that effectively limited the potential for ritual leaders and promoted a more egalitarian, spontaneous form of group worship. Further, the architectural layout of the different stupa complexes suggests that the laity, not the monks, were most interested in individual, meditative ritual. These conclusions stand in marked contrast to traditional discussions of early Buddhism derived from textual sources, which date from later periods.

In this paper, the architectural plans of 13 Buddhist stupa complexes of the first century B.C. through the second century A.D. are examined in order to assess the nature of ritual presentation in two forms of ritual architecture, one focusing on the Buddhist laity and the other dominated by the clergy. This analysis presents a new theoretical and methodological tool for archaeological studies of ritual architecture, while exploring an issue central to contemporary Buddhist studies - ritual practice and the relations between monks and laity. Before turning to the specifics of this analysis, I first provide some background on early Buddhist history and thought, focusing on specific rituals and on the role of the stupa in Buddhist worship. This is followed by a brief summary of previous anthropological approaches to ritual and ritual architecture before discussing the architectural methodology used in this paper. The locations of the 13 complexes are indicated on Figure 1.

This paper introduces a method, derived from theater and set design, for 


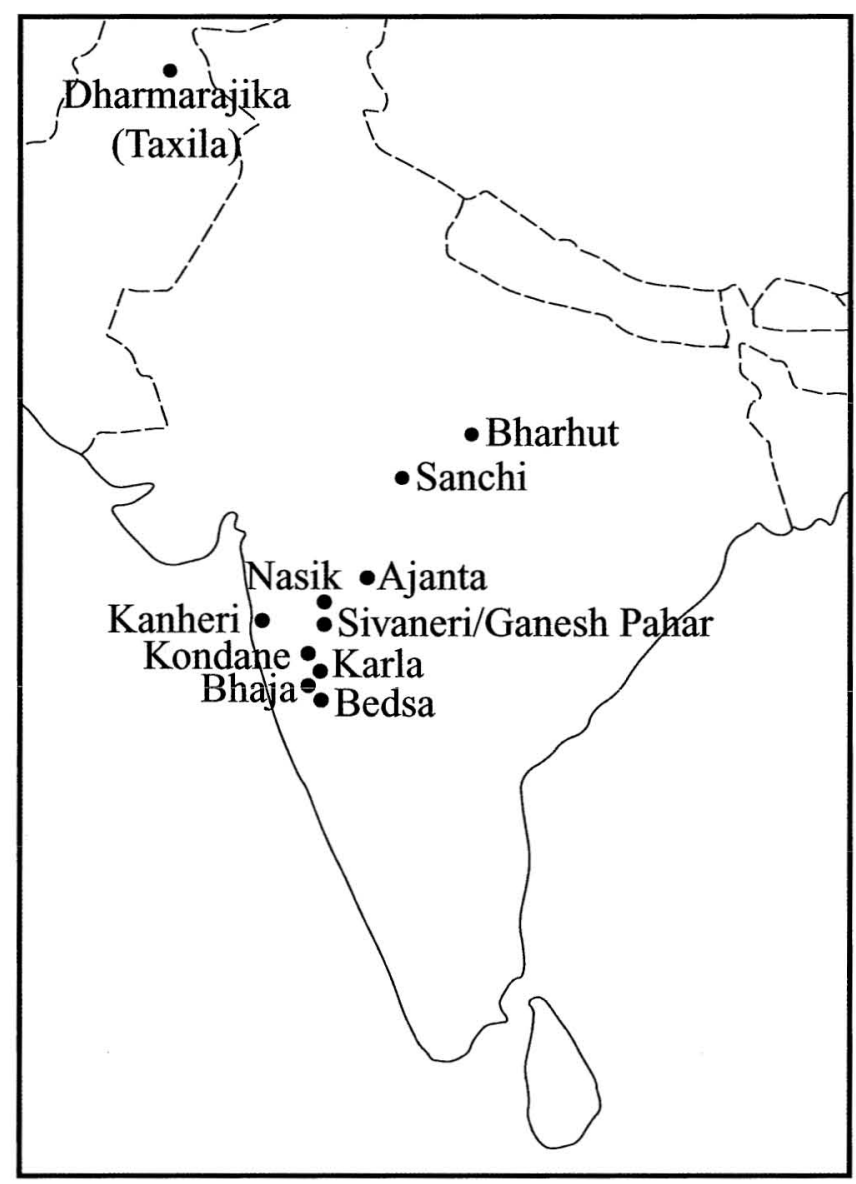

Fig. 1. Buddhist stupa complexes mentioned in this paper.

investigating religious ideology through architectural forms of presentation. Specifically, analyzing how someone or something is shown to an audience illuminates the goals of that presentation. This is accomplished by studying what is seen, how it is seen, and perhaps most importantly, what is hidden. In the case of early Buddhism, the architectural forms of presentation illustrate underlying tensions between the individual and group and between the clergy and the laity. While this paper presents an archaeological methodology for the examination of ritual architecture, it is strongly situated within the specific context of early historic South Asia. Applications in other social contexts are possible, but must be situated within their own specific social and historical contexts.

\section{THE HISTORICAL CONTEXT: EARLY BUDDHIST HISTORY AND THOUGHT}

Until recently, a general abstract of early Buddhist history was largely accepted by most scholars (Barnes 1995; Basham 1967; Chakrabarti 1995; Lamotte 1988). The Buddha lived from 563 to 483 B.C. Over the succeeding centuries Buddhism was 
accepted by growing numbers of followers, and religious sites were established at locales associated with the Buddha's life. In the third century B.C., the Mauryan emperor Asoka adopted Buddhism as a result of his remorse over the loss of life resulting from his conquest of the Kalinga on the eastern coast of India. After this, Asoka promoted Buddhism throughout South Asia through inscriptions proclaiming Buddhist doctrine and the support of Buddhist institutions. This catalyst propelled Buddhism from an important South Asian religion toward a path that would eventually lead to its expansion throughout Asia.

In the last decade, almost every point of this historical abstract has been challenged. Several researchers now argue the Buddha lived as much as a century later than previously believed (Bechert 1995). Coningham (2001) has convincingly shown that currently there is no archaeological evidence that any of the major pilgrimage sites associated with the Buddha existed prior to the Mauryas in the third century B.C. Even the centrality of Asoka in Buddhism has been questioned (Strong 1983, 1994; Thapar 1997). Recent interpretations of Asokan inscriptions have led some to argue that his rock edicts were actually intended to promote his own personal religion and glory, more than any single religious doctrine. The similarities with Buddhist doctrine are explained as the product of more generalized religious orientations common in multiple religious traditions throughout early historic South Asia (Thapar 1997). All of these reinterpretations reject earlier literal readings of Buddhist textual sources and studies that applied these readings uncritically to archaeological investigations (Coningham 1998, 2001; Schopen 1997).

Until the last few decades, the study of early Buddhism in South Asia was dominated by the reading of early monastic texts. However, the earliest extant texts date to the first century B.C. through third century A.D., several centuries after the Buddha lived. Based upon readings of this literature some scholars argued that stupa worship was initially the exclusive domain of the laity (see Coomaraswamy 1927; Lamotte 1988). The establishment of stupa worship among monks and nuns, and eventually the worship of Buddhist images, was argued to be the result of the clergy's contamination by the vulgar practices of the laity. This understanding of stupa worship was principally derived from a single passage in a first century B.C. Sri Lankan text, the Mahaparinibbana-sutta (Davids 1910; Trainor 1997), in which the Buddha is asked twice by his principle disciple, Ananda, what should be done with the Buddha's physical remains upon death. The Buddha first replies that Ananda should not concern himself with his mortal remains, but focus instead on meditation and nirvana. When asked again, the Buddha directed that his physical remains should be treated as if they were those of a cakravartin, a king with religious sanction. The Buddha specified that his remains be handed over to devout lay worshipers, cremated, and placed in a large stupa where they could be worshiped. Scholarly interpretations (e.g., Coomaraswamy 1927; Irwin 1980; Lamotte 1988) of this passage suggest that the first response was intended for Buddhist monks and nuns. The second response was intended for the laity who, with their poorer grasp of Buddhist principles, required the aid of direct worship to ease them toward the path to enlightenment.

This perspective has recently come under strong criticism by researchers such as Schopen (1997) and Lopez (1995) who focus upon inscriptions rather than sacred texts. These researchers argue that textual sources, since they significantly postdate 
the periods being discussed, cannot be taken to accurately reflect the practices of typical Buddhist monks or nuns. Instead, they argue contemporary inscriptions provide a much better, though different, picture of the early Buddhist clergy. In evaluating the epigraphic evidence for both the accumulation of wealth and worship of the stupa by monks and nuns. Schopen (1997:31-32) states,

None of this accords very well, if at all, with the received views on the matter, with
views that maintain that there is a sharp distinction between the kinds of religious
activities undertaken by monks and the kind of religious activities undertaken by
laymen, and with the view that cult and religious giving were essentially and over-
whelmingly lay concerns in the Indian Buddhist context. In fact, if we stick to what
we actually know, it would appear that something very like the opposite was the
case: we know for certain from inscriptions that from ca. 150 B.c.E. - that is to say,
from our earliest knowable donative inscriptions and well before we can have defi-
nite knowledge of the textual tradition- monks and nuns formed a substantial pro-
portion of those involved in donative, merit making activities connected with the
stupa cult.

Schopen also notes the ubiquitous association between Buddhist monasteries and stupas from the third century B.C. onward. When combined with the epigraphic evidence, he concludes that "from the very beginning of our evidence, [the stupa cult was] both monastically controlled and monastically dominated" (Schopen 1997:34). Schopen concludes his analysis by rejecting the traditional monk/laity distinction that earlier, textually focused Buddhist scholars had taken as a fundamental premise. Inasmuch as both clergy and laity were involved in the stupa cult, this archaeological analysis supports Schopen's rejection of the traditional monk/laity distinction. However, the forms of presentation used at different types of stupa complexes suggest that there is still value in this distinction. Rather than the simple worship or nonworship of stupas, the laity/monk distinction is evident in the different types and intentions of ritual each engaged in within stupa complexes.

By the first century B.C., Buddhism was one of several prominent religions in South Asia, along with Jainism (see Dundas 1992) and the antecedents of modern Hinduism (see Basham 1989; Chakrabarti 2001). Buddhist worship focused upon stupas, both large stupas containing relics and smaller stupas within monastic establishments. Buddhist religious centers received the patronage of kings, guilds, merchants, bankers, and even the clergy themselves. Despite textual prohibitions, the accumulation of wealth by the monastic establishments and specific monks is well documented in contemporary inscriptions. During this period, many of the larger stupas, dating to at least Mauryan times, were enlarged to the form that exists today. In addition, numerous monasteries of both wood and stone were established throughout the subcontinent. These monasteries were centers of learning, teaching, and the writing of religious treatises. The corpus of material dating from the first century B.C. through the third century A.D. includes the writings of many different sects, each with different approaches to, and understandings of, Buddhist thought. The intricacies of these doctrines, and their philosophical subtlety, make it difficult to summarize Buddhism succinctly (though see Lamotte 1988; Lopez 1995).

Underlying almost all the Buddhist traditions is the concept of the four noble truths. The first states that life is inherently sorrowful. The second noble truth is that all sorrow stems from desire, and ultimately all desire stems from the false 
belief in the self. The third noble truth states that if you can cease belief in the self, desire and sorrow must logically also cease to exist. This state, without knowledge of the self, desire, or sorrow, is nirvana. The fourth noble truth specifies how this can be achieved. Specifically, nirvana is attained through ethical behavior, meditation, and the gathering of wisdom. Meditation allows an individual to see past the illusion of the self, while wisdom allows an understanding of nirvana. Together, these practices confer merit on the worshiper, speeding the path to nirvana. A person who successfully enters the state of nirvana becomes an arhat, or 'worthy one.' Lopez (1995) describes two paths that Buddhists recognized for becoming an arhat. The first is a sravaka, or 'listener.' These are individuals who have heard the Buddha's words, and have acted upon them appropriately. In contrast, pratyekabuddhas achieve enlightenment in solitude.

The identification of two forms of arhats underscores a central issue in early Buddhism. With its emphasis on the individual attainment of nirvana, the creation and maintenance of a cohesive Buddhist congregation was exceedingly difficult. With the widespread adoption of Buddhism in Mauryan and later periods, the individualizing aspects of the religion needed to be tempered with practices that promoted group cohesion. Thus, it is not surprising that an extensive body of literature developed describing the rules and obligations developed to overcome the individualizing tendencies of the religion (Lopez 1995). This tension between the group and individual is clearly illustrated in the two forms of arhat. Solitary meditation is the individualizing path of the pratyekabuddha. The sravaka path on the other hand, emphasizes the need for formal learning from the Buddha, his disciples, or a leading monk. As demonstrated below, this tension between the individual and group is manifested in the layout of Buddhist temples and in the rituals conducted within them.

For this study, I identify three principal kinds of ritual that occurred within stupa complexes. The first, individual ritual, corresponds with the more meditative and solitary aspects of Buddhism. It is important to note that individual ritual need not imply that only a single individual is present within a given ritual space. Instead, individual worship is defined as direct interaction between an individual and the object of worship. It does not require other individuals, but it does not preclude others from worshiping at the same time. In stupa complexes, the primary form of individual ritual was circumambulation of the stupa. Through circumambulation, an individual accumulated merit, assuring a better position in their next life and faster attainment of nirvana. Circumambulation is also meditative, as worshipers combined steady physical movement with religious thought. As discussed below, most large stupas contain a circumambulatory path for this ritual.

The other two types of rituals involve multiple participants. It has long been recognized that group ritual has the effect of promoting social cohesiveness or solidarity (Durkheim 1915 [1995]). Given the individualizing tendencies of early Buddhism, group ritual was particularly important for creating and maintaining a cohesive Buddhist community. However, not all group rituals are the same. Here I distinguish between group rituals that promote egalitarian relationships between members of a group, and rituals based upon the common identification with a single leader. The first is labeled communal ritual. Communal ritual is a group phenomenon that requires no ritual specialists or other individuals leading worship. 
All participants are involved more or less equally. Communal ritual is worship between a group and an object or action. Corporate ritual, in contrast, is group worship of an object or action that is directed or mediated by a ritual specialist or other individual. In corporate ritual, a person (or small group of people) is elevated into a leadership position. Such positions need not be permanent or hereditary for corporate worship to occur. While the architectural form varies, all large stupas contain an assembly area in which either communal or corporate ritual was practiced.

\section{ARCHAEOLOGY AND RITUAL ARCHITECTURE}

The methodology for interpreting ritual presentation discussed below builds upon several recent discussions in anthropology and elsewhere of architecture and ritual experience. For example, Bourdieu $(1973,1977)$ has focused on the dialectical relationship between space and the people who create and inhabit it-arguing that people both manipulate spaces and their meanings, and are also conditioned, or habituated, by them (see also Giddens 1984). In this paper, this is taken as a given. More specific investigations of architecture have involved a variety of approaches. For domestic architecture, the influence of structuralism has been profound (see Bourdieu 1973; Kent 1990; Pearson and Richards 1994; Tambiah 1969; see also Rapoport 1982). While the identification of oppositions and classification in architecture has been productive for the reconstruction of symbolic frameworks, the concern here lies with ritual practice, and not deeper structural 'meanings.'

In recent years religious architecture and ritual has become an increasing focus of archaeological inquiry (e.g., Bradley 1990; Carmichael et al. 1994; Garwood et al. 1991; Kowalski 1999; Smith and Brookes 2001). Scholars have also begun to address the experiential aspects of ritual architecture (e.g., Bradley 1998; Moore 1996; see also Tilley 1994). These studies emphasize issues such as patterns of visibility, sensory experiences, movement, and access in particular architectural forms. A valuable example is Moore's (1996) study of distance and elevation on the visual perception of ritual action in pyramid complexes in Coastal Peru. $\mathrm{He}$ suggests that the form of ritual practiced in large ritual complexes could be limited by the spectators' ability to perceive ritual at a distance. For example, a figure standing atop a large pyramid would have an extremely difficult time being seen and heard. Ritual in these contexts would most likely involve large movements with little emphasis on speech.

Hillier and Hanson (1984) have also emphasized the experiential aspects of spaces in their focus on patterns of access and movement through architectural complexes. While concealment and restriction are central to their arguments, for the most part, their analysis considers concealment in terms of the relative difficulty in gaining admission into an architectural interior. In this paper, visibility is emphasized, rather than access, as a key factor in the architectural layout of a single ritual space. Given the focus on religious architecture, this research is also situated within the broader context of ritual studies that have long been a focus of archaeological and anthropological study (for a recent review see Bell 1997). Specifically, this paper focuses on two foundational concepts in this field: Durkheim's (1915 [1995]) “social solidarity" and Weber's $(1958,1978)$ "routinization 
of charisma." While recent trends in anthropology have called into question the often unitary conception of society that underlie both Durkheim and Weber's work, if issues of power, resistance, and factionalism are added to them, they remain powerful and important concepts for examining ritual in general, and early Buddhism in particular.

\section{THE PRINCIPLES OF PRESENTATION}

Presentation, in the most basic sense, refers to the manner in which an object or action is shown to a person or group of people. Presentation is not synonymous with viewing. While it can be safely assumed that, for the most part, objects that are presented are also viewed, presentation emphasizes the intentions of the person or people who are showing an object or performing an action, while viewing focuses upon the reactions of those who see the object that has been presented. Thus, presentation refers to the intended affects on viewers that need not be the actual effects. By examining the forms of presentation within stupa complexes, this paper focuses upon the intentions of the people who designed and built stupas. That said, not all forms of presentation will be acceptable to the people to whom the presentation is directed. The audience of a presentation always enters with its own ideas of what should be presented and how. The final form of presentation is the result of a negotiation between the goals of the presenters and the desires of the audience. This may be particularly the case when the audience is partially responsible for the costs of construction and maintenance of a presentation space, as was the case for many stupa complexes.

Different goals or intentions in presentation often result in different architectural forms of presentation. This initial assumption must be modified by some pragmatic concerns. The final form of presentation is always a negotiation between the intended goals of presentation, the specific cultural and historical context in which it occurs, the expectations of the audience, and the physical limitations of architecture. Within these constraints, a large amount of variation exists in architectural forms. In ritual spaces, presentation can take many different forms, each with corresponding strengths and weaknesses for reinforcing the goals of the rituals that are conducted within them. Thus, it is possible to read back from the presentational form of a ritual space the goals that underlie its construction.

The following analysis relies heavily on techniques derived from theatrical set design (see Payne 1993:37-51). Set designers work within theatrical spaces, halls, and arenas, which roughly correspond to the forms of ritual space in early Buddhist religious structures. Modern set designers note that halls foster more formal actor-audience relationships, while arenas are more participatory. While the terminology of halls and arenas is derived from western theater, the same concepts are found in the Natyasastra, an early Indian treatise on theater and dance (Muni 1986; Sharma 1987). It should be noted that while valuable, the Natyasastra dates to the second or third century A.D., and cannot be used for direct interpretation of the stupa complexes discussed in this paper. The Natyasastra has large sections devoted to the design of nine different types of theaters, including several types of halls and arenas. In relation to presentational forms, it states that formal plays concerning the gods should be presented in halls, while circuses, dancing acts, and comedies should be presented in arenas. Like Western theatrical traditions, the 
Natyasastra recognizes that more participatory forms of theater belong in arenas, while more formal religious plays and instruction belong in halls. Taken as a general statement of early South Asian views on presentation, the Natyasastra demonstrates that the principles of presentation in Western set design are relevant to an analysis of early Buddhist stupa complexes.

An analysis of what can and cannot be seen from any given point with a theater, sightlines (Payne 1993), is a valuable technique to determine the nature of theatrical presentation. Sightlines can also be used to address the likely forms of presentation for individual, communal, and corporate participation in ritual. Individual ritual should emphasize the object of worship, and minimize the distraction of other individuals. Thus, if the goal of presentation is to facilitate individual ritual, the layout of the architecture should limit the viewing of anything other than the object of worship. In contrast, communal participation in ritual requires that the audience see other audience members and interact with them while still maintaining the ritual focus. Finally, corporate participation in ritual places the focus on the object of worship and the intermediaries who direct worship.

The most obvious form of presentation for individual ritual is a small room adjacent to, or containing, the object of worship. The walls of the room would block from view all other potential distractions while the ritual focus would be clearly visible. In fact, in later Buddhist periods, this format was adopted for individual ritual. But, during the period addressed in this paper, pragmatic concerns forced a modification of this ideal form. At many stupa complexes, large numbers of people engaged in individual ritual simultaneously. A small room, or even several small rooms, could not accommodate all worshipers. Rather, as discussed below, individual ritual occurred in circumambulatory paths, which allowed for a large number of people to engage in individual worship simultaneously.

As alluded to earlier, two presentational forms that closely relate to communal and corporate worship are arenas and halls. An arena is a presentational space in which the audience surrounds the object or action being viewed while a hall places the audience on only one side of the object or action. This basic difference in layout creates fundamental differences in the sightlines of these spaces. In an arena space, the faces of other individuals are visible as a backdrop to the action or object on which the presentation is focused. While actively viewing this object or action, each individual cannot help but see how other audience members are reacting. The sightlines in an arena highlight both the object and the audience, promoting communal participation in ritual.

Along with fostering communal ritual, arenas also hinder the performance of corporate ritual. In an arena, there is no place where a ritual specialist could stand and command the attention of the entire audience. The ritual specialist would always have his or her back toward half of the audience no matter which way he or she faced. In an arena in which the ritual focus is elevated, such as a stupa, this problem is even more pronounced. Unless the ritual specialist stood upon the top of the stupa, which was almost certainly prohibited, most of the audience could not have even seen the back of the ritual leader. Any audience member who did not want to listen could simply walk around to the other side of the stupa and ignore the ritual leader.

In contrast, the hall form lends itself to ritual mediators. Unlike arenas, halls downplay interaction between audience members. While the principal object or 
action is clearly visible, only the backs of fellow audience members' heads can be seen. Without the ability to see other peoples' faces, only the grossest of reactions can be gauged from body language and some vocalization. The sightlines of a hall help direct attention towards a specific focus, allowing an individual or group of individuals to command the attention of the audience. By standing between the ritual focus and the entire audience, a ritual specialist can establish himself or herself as a ritual mediator, both physically and metaphorically. Thus, the hall form of presentation is most appropriate for corporate ritual.

Though different presentational forms lend themselves to different ritual goals, this does not mean that architecture determines ritual. It should be expected that, at times, halls were used for communal ritual and vice-versa. The space might even be temporarily altered through wall hangings, screens, or furniture in support of that ritual use. That said, ritual spaces are typically built to support the most common form of ritual expected to be performed within them. Further, given the centrality of stupa worship in early Buddhism, it seems unlikely that ritual within stupa complexes would be routinely redirected away from its ritual focus.

\section{STUPAS SELECTED FOR ANALYSIS}

For the purposes of this analysis a total of 13 different stupa complexes have been analyzed. Three of these are open-air stupa complexes, and the remainder are rock-cut stupa complexes. The complexes selected for this analysis were chosen because of their relatively high degree of preservation and reasonably clear chronology. Even with these selection criteria, not all can be used in all of the spatial analyses in this paper. Particularly for the open-air stupa complexes, the image developed is a composite of all three complexes in the database. Where one element is missing at one complex, another may retain these architectural elements and vice-versa.

The stupas considered in this analysis are only a sample of the stupas that existed in the first century B.C. Some have been completely destroyed and others are not sufficiently preserved. This sample includes all of the intact stupa complexes that can be firmly ascribed to the period from the first century B.C. to the second century A.D. Other, less well-preserved stupas not included in this analysis seem to follow similar architectural patterns to those described in this paper. All of the stupa complexes share several common elements (for more extensive discussions of stupa architecture see Brown 1965; Mitra 1971; Snodgrass 1992). First, all have a stupa as the focus of the architectural space. The stupa dome is usually raised on a cylindrical foundation, or drum. Second, these stupa complexes all have two ritual spaces: an assembly area for group ritual and a circumambulatory path for individual ritual. Third, all have some form of barrier to divide the two ritual spaces. In open-air stupas, this is accomplished with a high railing. In rock-cut stupas, columns achieve the same effect. While open-air and rock-cut stupa complexes share several architectural elements, their arrangement varies. These differences in spatial organization have a direct impact on the forms of presentation at these two types of stupa complex and suggest differences in the forms of, and value ascribed to, individual and group ritual.

The three open-air stupa complexes used in this analysis are Sanchi, Bharhut, 
Table i. Open-Air Stupa Complexes

\begin{tabular}{lcc}
\hline STUPA COMPLEX & CONSTRUCTION DATE & \multicolumn{1}{c}{ SOURCES } \\
\hline Sanchi & c. 100 B.c. & $\begin{array}{c}\text { Cunningham 1854 [1997]; Luders 1912; Marshall } \\
\text { and Foucher 1983; Shaw 1999, 2000 }\end{array}$ \\
Bharhut & c. 100 B.c. & Barua 1979; Cunningham 1876 [1962]; Luders 1912 \\
Dharmarajika & c. 100 B.c. & Marshall 1951 [1975]; Sarkar 1966 \\
\hline
\end{tabular}

and Dharmarajika (see Table 1). The earliest stupas at all three complexes were constructed in the third century B.C. However, all were greatly enlarged and modified in the first century B.C. At Dharmarajika stupa later construction continued to modify the general architectural form. This resulted in changes to the stupa, and the destruction of the railing (Marshall 1951 [1975]). Bharhut is very poorly preserved. Before the first archaeological excavations and research, the stupa had been extensively mined for its bricks (Barua 1979; Cunningham 1876 [1962]). While the railings and gateways have been found and reconstructed, the dome is now almost completely missing. The importance of Bharhut lies in the large number of inscriptions and reliefs found on its railings. Three distinct stupas have been found at Sanchi, each reconstructed several times. Only Stupa 1 is included in this analysis. While some excavations occurred in the early nineteenth century, Cunningham's (1854 [1966]) excavations from the mid-nineteenth century provided the first systematic study. His reports still provide among the best descriptions of Stupa 1 and its associated monuments.

All three open-air stupa complexes follow the same architectural pattern (Fig. 2). The central stupa is generally large. Stupa 1 at Sanchi is over $12 \mathrm{~m}$ high, with a diameter of roughly $32 \mathrm{~m}$. The more heavily damaged central stupas at Bharhut and Dharmarajika appear to have been comparable in size. The large central stupa mound at open-air complexes is immediately surrounded by a circumambulatory path, or at Sanchi, paths. Outside of the path, surrounding the entire stupa, lies a large assembly area defined by a low wall. A large number of haphazardly placed 'votive' stupas were found within the assembly area at Sanchi and Dharmarajika (Mitra 1965). Between the circumambulatory path and assembly area is a high railing, which acts to separate the two ritual spaces. This railing is sufficiently high, and elaborate, to effectively block the view from one ritual space to another. Gates are located in the railing at the cardinal points to allow for access between the two ritual spaces. Excavations have revealed that the central stupa of large open-air complexes seem to consistently contain relics, often attributed to the Buddha himself.

Open-air stupa complexes are generally recognized as having been pilgrimage locations. Several lines of evidence support this. Pilgrimage is recognized in assorted versions of the Mahaparinibbana-sutta (Schopen 1997:115-119), several of which record the Buddha as stating that pilgrimage confers merit upon the pilgrim. In other sections, the Buddha is recorded as stating that those people who die while traveling to or from a pilgrimage center will attain nirvana. In addition to these literary sources, three other lines of evidence support the claim that open-air stupa complexes were pilgrimage locations. First, open-air stupa complexes are very large. While monasteries were present at these sites, the space 

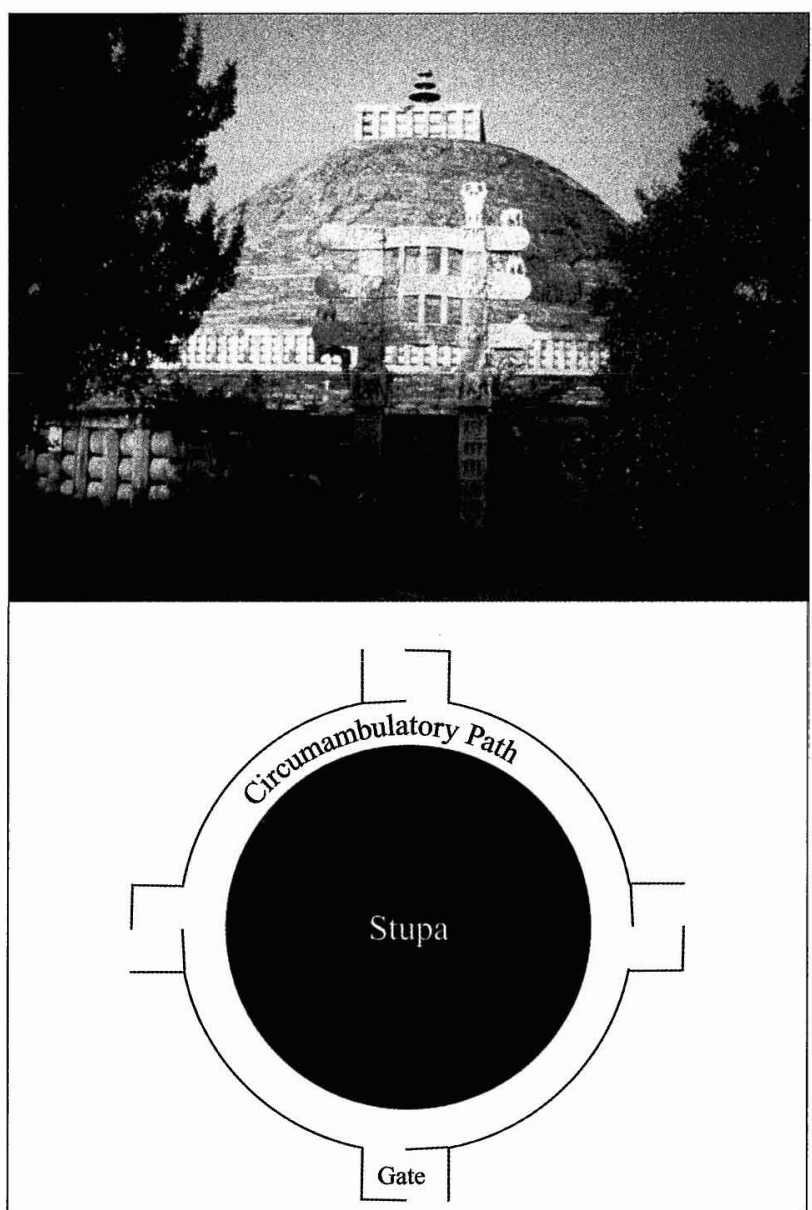

Assembly Area
Fig. 2. Sanchi 1 (courtesy of the Vijayanagara Metropolitan Survey) and schematic diagram of an open-air stupa complex.

available for worship was far greater than needed by the resident clergy. Second, no doors block access to either the circumambulatory path or the open-air stupa complexes as a whole. As will be discussed later, the entrances to the circumambulatory path were carefully designed to allow the free movement of people, while maintaining the separation between different worship areas. Third, inscriptions recording donations to these stupas list many different, and often distant, home towns. Not only do these inscriptions help reinforce the suggestion that open-air stupa complexes were pilgrimage sites, they also provide a means to identify some of the specific social groups who visited the complexes.

Donation inscriptions from Sanchi and Bharhut show that people traveled great distances to worship at the stupa (Basham 1967; Cunningham 1854 [1966], 1876 [1962]). The inscriptions used in this analysis were taken only from locations directly associated with the stupas under investigation. The translations of these inscriptions come from Cunningham (1854 [1966]), 1876 [1962]), Luders (1912), and Barua (1979). 
Donatory inscriptions provide a record of people who supported Buddhist institutions. Donations had several purposes. Among the most important was the accumulation of merit, speeding the path to nirvana. It is also likely that individuals gave to stupas to help keep these institutions solvent. Sanchi and Bharhut have 299 readable inscriptions carved into the railings that surround their circumambulatory paths. Along with listing home towns, many inscriptions list the donor's occupation. An analysis of the frequencies of donation yields some surprising results. These include an almost complete lack of royal donations. Given their prominence in the scholarly literature, far more were expected. Likewise, merchants and craftspeople seem greatly under-represented in relation to the emphasis they receive from many researchers (Basham 1967; Cunningham 1854 [1966]; Thapar 1966). The two dominant donor groups to open-air stupa complexes are the clergy and those people who do not list an occupation (Fig. 3). The importance of the support that monks provided to Buddhist monasteries has been noted for over a century (Basham 1967; Cunningham 1854 [1966]; Schopen 1997; Thapar 1966). What is clear from these inscriptions is that the clergy, despite textual proscriptions to the contrary (de Jong 1987; Lamotte 1988; Schopen 1997), had access to wealth and donated it to Buddhist institutions.

The numerous inscriptions that do not list an occupation are more difficult to interpret. Given the numerical importance of this group in supporting the activities of open-air stupa complexes, an understanding of their position in society is critical. It is possible that these donors were members of lower status occupational groups, such as agriculturists, lower status merchants and craft specialists, and other occupations. These people may not have chosen to list their occupations since little prestige was given to them. Alternatively, these inscriptions could sim-

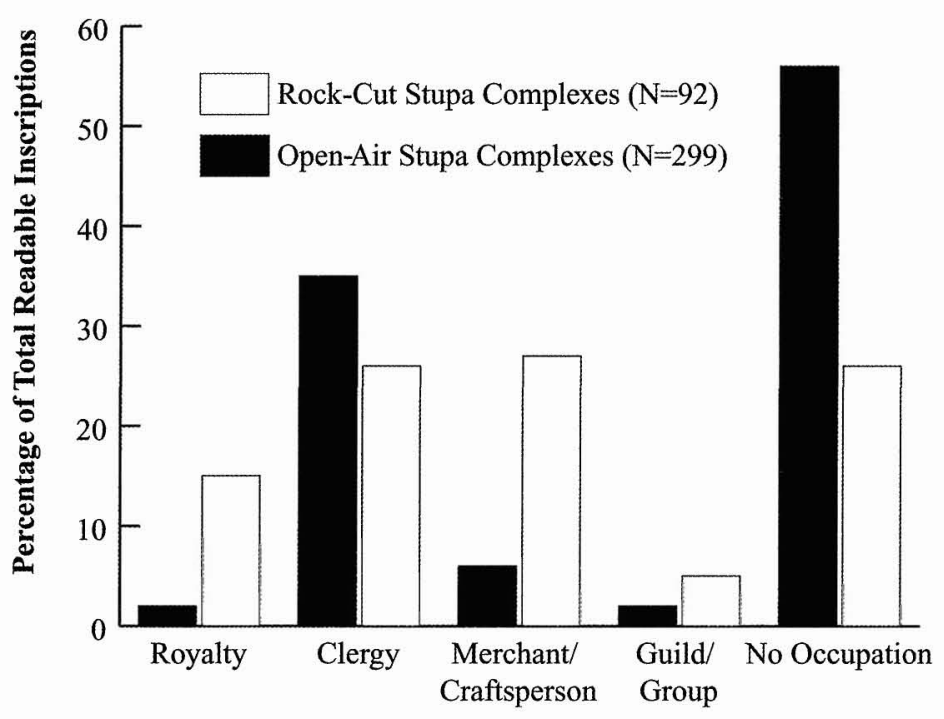

Occupation of Donor

Fig. 3. The frequency of donations to rock-cut and open-air stupa complexes by occupation of the donor. 
Table 2. Rock-Cut Stupa Complexes

\begin{tabular}{|c|c|c|}
\hline STUPA COMPLEX & CONSTRUCTION DATE & SOURCES \\
\hline Kondane I & с. 95 в.с. & $\begin{array}{l}\text { Dehejia 1972; Fergusson and Burgess } 1880 \text { [1988]; } \\
\text { Nagaraju } 1981\end{array}$ \\
\hline Bhaja XII & с. 90 B.C. & $\begin{array}{l}\text { Dehejia 1972; Fergusson and Burgess } 1880 \text { [1988]; } \\
\text { Nagaraju } 1981\end{array}$ \\
\hline Ajanta X & c. 80 B.C. & $\begin{array}{l}\text { Dehejia 1972; Fergusson and Burgess } 1880 \text { [1988]; } \\
\quad \text { Ghosh 1968; Nagaraju 1981; Spink } 1991\end{array}$ \\
\hline Ajanta IX & с. 65 в.с. & $\begin{array}{l}\text { Dehejia 1972; Fergusson and Burgess } 1880 \text { [1988]; } \\
\text { Ghosh 1968; Nagaraju 1981; Spink } 1991\end{array}$ \\
\hline Nasik XVIII & c. 60 B.C. & $\begin{array}{l}\text { Dehejia 1972; Fergusson and Burgess } 1880 \text { [1988]; } \\
\text { Nagaraju } 1981\end{array}$ \\
\hline Karla VIII & с. 60 в.С. & $\begin{array}{l}\text { Dehejia 1972; Fergusson and Burgess } 1880 \text { [1988]; } \\
\quad \text { Nagaraju } 1981\end{array}$ \\
\hline Bedsa VII & c. 40 B.C. & $\begin{array}{l}\text { Dehejia 1972; Fergusson and Burgess } 1880 \text { [1988]; } \\
\text { Nagaraju 1981 }\end{array}$ \\
\hline Ganesh Pahar VI & c. 120 A.D. & $\begin{array}{l}\text { Dehejia 1972; Fergusson and Burgess } 1880 \text { [1988]; } \\
\text { Nagaraju 1981 }\end{array}$ \\
\hline Kanheri III & c. 120 A.D. & $\begin{array}{l}\text { Dehejia 1972; Fergusson and Burgess } 1880 \text { [1988]; } \\
\quad \text { Nagaraju 1981; Ray } 1994\end{array}$ \\
\hline Sivaneri LXVI & c. 175 A.D. & $\begin{array}{l}\text { Dehejia 1972; Fergusson and Burgess } 1880 \text { [1988]; } \\
\quad \text { Nagaraju } 1981\end{array}$ \\
\hline
\end{tabular}

ply be from merchants and clergy who, for whatever reason, did not list their occupation. For now, the discussion of donors who list no occupation will necessarily be limited. It is assumed that those people who donated to open-air stupa complexes were also the most likely to make pilgrimages to them. By combining the information on the size of the open-air stupa complexes, the absence of doors to block access, and the inscriptions carved into their railings, it is possible to argue that open-air stupa complexes were dominantly pilgrimage sites, potentially focusing on less prestigious classes of the Buddhist laity.

As with the open-air stupa complexes, the ten rock-cut stupa complexes in this study were chosen for the quality of preservation of architecture dating from the first century B.C. to the second century A.D. (Table 2). The dates of construction used in this paper follow those proposed by Dehejia (1972). Two points on the dating of the rock-cut stupa complexes should be addressed. First, while some of the complexes used here date as much as a century and a half later than the openair complexes discussed earlier, their use overlaps with the open-air complexes. Second, architectural elements in the earliest rock-cut complexes (e.g., Kondane) demonstrate that they were modeled on wooden prototypes (Brown 1965). While these have not been preserved, their presumed dates of construction would be at least contemporary with the open-air complexes. This analysis of rock-cut stupa complexes focuses upon the main hall containing a stupa, the chaitya hall, and associated monastic quarters, viharas. In all of the complexes, the stupa is located at one end of a columned apsidal hall (Fig. 4), opposite the entrance and a large window, which provides the only natural light. The assembly area lies between the entrance and the stupa. Encircling both the stupa and assembly area is the circumambulatory path. Like the railing in open-air complexes, columns sep- 


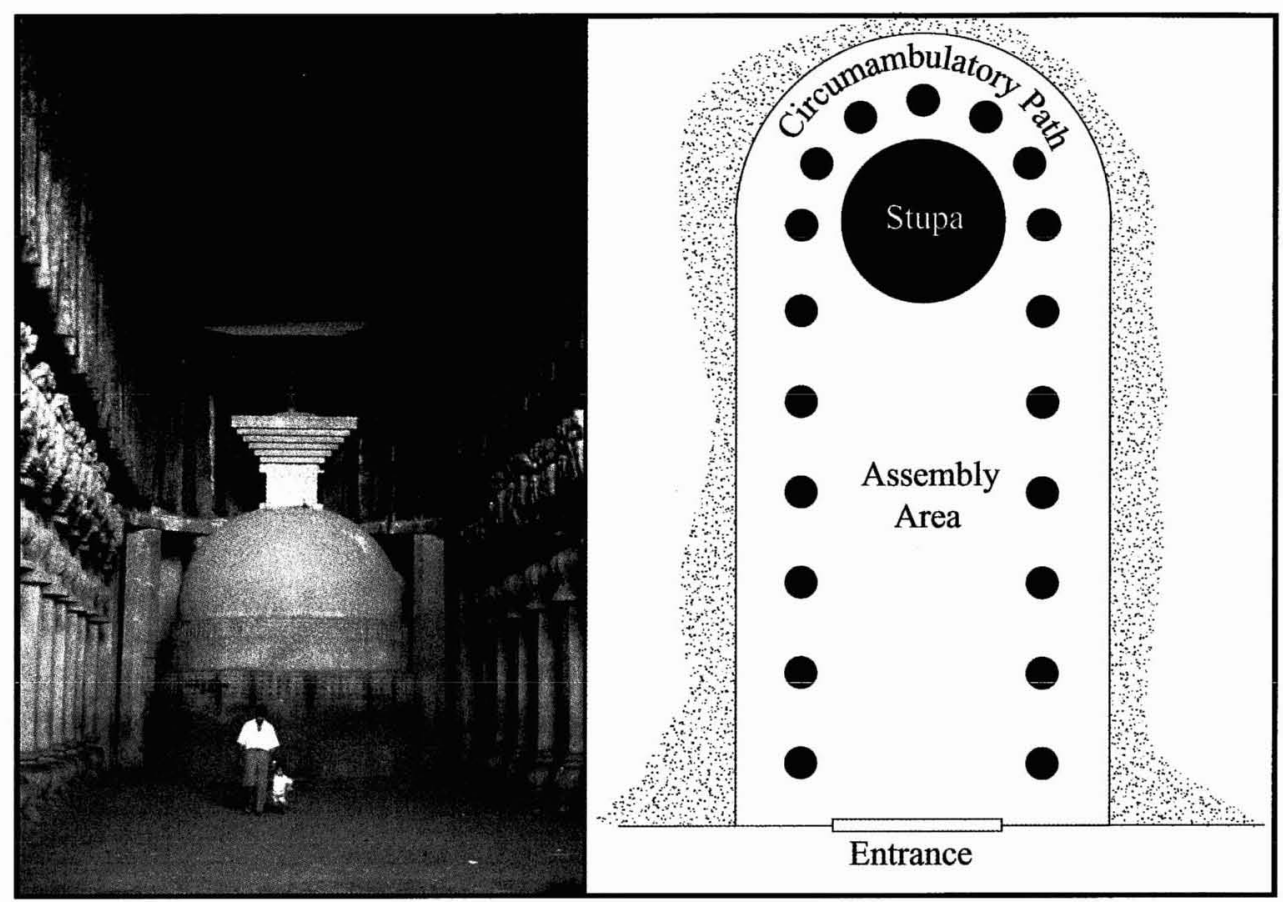

Fig. 4. Karla VIII Chaitya hall (photograph by author) and schematic diagram of a rock-cut stupa complex.

arate individual and group ritual spaces within rock-cut stupa complexes. Given this layout, only the assembly area is illuminated to any significant degree by the window. Without the aid of oil lamps, the circumambulatory path would have been bathed in half-light-though this may have served the meditative rituals performed there.

Unlike open-air stupa complexes, the stupas in most rock-cut complexes did not contain relics, although a few complexes did (e.g., Bhaja XII; see Mitra 1971). The lack of relics suggests that stupa worship in rock-cut stupa complexes was different than at the large, open-air complexes. The reasons for these differences may be temporal, but they also relate to the constitution of the audience of worshipers. Initially, stupas were worshiped for what they contained, relics of the Buddha conceived as the presence of the living Buddha (Schopen 1997). Over time, the stupa became symbolically associated with the Buddha (Irwin 1980; Snodgrass 1992). Stupas served to symbolically represent the Buddha, with or without specific relics (Trainor 1997). This marks a change from the direct worship of the Buddha's remains, to a more abstract worship of the concept of the Buddha. In the first century B.C. these 'relicless' stupas exist only in rock-cut stupa complexes, and it is reasonable to assume that this change was focused upon the audience that could be expected in the chaitya halls of rock-cut stupa complexes. To understand whom this audience was it is necessary to understand the overall function of the rock-cut stupa complexes. 
While almost all Buddhist scholars agree that rock-cut stupas were primarily monastic institutions, there is a great deal of disagreement over what, if any, secondary functions these monasteries might have had. Earlier researchers (Basham 1967; Cunningham 1854 [1966]; Fergusson and Burgess 1880 [1988]; Sastri 1966) emphasized the role of the royalty in financing and supplying the needs of the resident monks. Later researchers saw the monks as relatively autonomous from the royalty by the first century B.C. (Brown 1965). More recently, several scholars have emphasized the location of many rock-cut stupa complexes along trade routes to argue that these monastic institutions were heavily involved in economic concerns including long-distance trade and agricultural production (Heitzman 1984; Lahiri 1992; Ray 1986, 1989; Thapar 1966; see Morrison 1995 for a critique of these arguments). For all researchers, the main lines of supporting evidence are the donation inscriptions found in almost all rock-cut stupa complexes. For the following analysis, only inscriptions from the halls and contemporaneous monastic cells were included (translations from Dehejia 1972; Ghosh 1968; Nagaraju 1981).

Figure 3 illustrates that there is evidence to support the involvement of many different social groups in the maintenance and construction of rock-cut stupa complexes. In comparison to open-air complexes, there is a higher percentage of inscriptions from both royalty and merchants. The clergy still make up a large percentage of the donors. Given this pattern, it seems these monastic institutions were heavily involved with all of the groups listed above, perhaps without an emphasis on any one. Perhaps more interesting is the dramatic decrease in the number of donation inscriptions from people who do not list an occupation. While still an important component of the total inscriptions, they are roughly half as frequent as they are in open-air stupa complexes. If, as suggested earlier, these inscriptions represent a less prestigious class of Buddhists, this difference in the frequency of gifts may suggest that these monastic centers were not as favored by lower status Buddhists. This in turn reinforces the argument that rock-cut stupa complexes were not established pilgrimage locations.

One final line of evidence to support a more restricted role for monasteries is the presence of doors at the entrances to the chaitya halls. This suggests that access to the central stupa was restricted, perhaps only to resident monks. Taken as a whole, these data suggest, as Brown (1965:13) has argued, that these monastic communities were primarily "retreats," where clergy could "conduct their observances undisturbed by the distractions of any human environment."

It should also be remembered that Buddhism was not a single unified denomination in the period addressed in this paper (Coningham 2001). Multiple rival sects are documented in contemporary textual and epigraphic sources. The architectural differences investigated in this paper may be a product of comparing the ritual practices of different Buddhist sects, though this cannot be determined with present evidence. Another possibility is that individual sects may have had multiple monasteries to serve different roles. Where some sect members lived adjacent to large open-air stupa complexes, others lived a reclusive life in the more isolated rock-cut stupa complexes. The role of 'forest' monks has been well documented in Sri Lanka in both modern times (Carrithers 1983) and archaeologically in periods contemporary with the monasteries discussed here (Coningham 1995). 


\section{ARCHITECTURAL ANALYSIS: RITUAL PRESENTATION IN STUPA COMPLEXES}

All of the stupas examined in this study have both a circumambulatory path and assembly area. Since the forms of ritual conducted in each area could be potentially distracting to the other, some form of separation was needed between the different ritual areas. As discussed above, this separation was accomplished with the railings at open-air stupa complexes and with the columns at rock-cut stupa complexes. At both open-air complexes from which information is available (Sanchi and Bharhut), the railings are well over the height of a person. While these railings are important as decorative elements in the architectural design, and the gateways provide surfaces on which to carve religious scenes, neither function seems to fully explain the particular forms of the railings or gateways. Circumambulation is an individual ritual, but the assembly areas were used for group worship. It would be distracting for the people in the pathway to become enmeshed within the assembly area. Likewise, the sight of people silently walking around the stupa would be distracting for the more direct forms of worship practiced in the assembly area. The railings acted to block the view of each ritual area from the other. This served to reduce the tension inherent in the competing ritual demands of the space.

This point can be further illustrated by an analysis of the gateways that link the circumambulatory path with the assembly area. At both Sanchi and Bharhut, the gates are L-shaped. By constructing them in this form, the potential for looking into or out of the circumambulatory path is reduced, while still allowing for unobstructed entrances and exits to the path. As such, the gates served to promote the practice of different ritual forms within the same overall religious structure (see Fig. 5).

This same separation is achieved with columns in rock-cut chaitya halls. In rock-cut stupas the circumambulatory path surrounds the assembly area. While the columns are spaced to allow people to move between the two areas of worship, when facing the stupa in the assembly area it is not possible to see behind the columns. Likewise, when in the circumambulatory path, the worshipers' sightlines would parallel the rows of columns, effectively shielding the assembly area. Unlike the railings at Sanchi and Bharhut, the columns also act to prevent the viewing of the stupa from the circumambulatory path. In the open-air stupas, both worship areas have the ability to view the dome. At rock-cut stupa complexes the columns also block viewing of the dome itself, yielding a fundamental difference between the sightlines of these two forms of presentational architecture (see Fig. 6).

The presentational forms of the assembly areas of open-air and rock-cut stupas are also consistently different. The assembly areas of the former are arenas, while the assembly areas in the latter are halls. As discussed earlier, arenas are more conducive to communal ritual while halls foster corporate ritual. The consistent presentational differences between open-air and rock-cut stupas may reflect important differences in the forms of ritual conducted within them. The large arenaform assembly area open-air stupa complexes allowed worshipers to engage and participate with other worshipers while maintaining a focus on the stupa, which rose above the railings defining the circumambulatory path. Given this presentational form, a potentially lively form of worship seems possible. This idea is rein- 


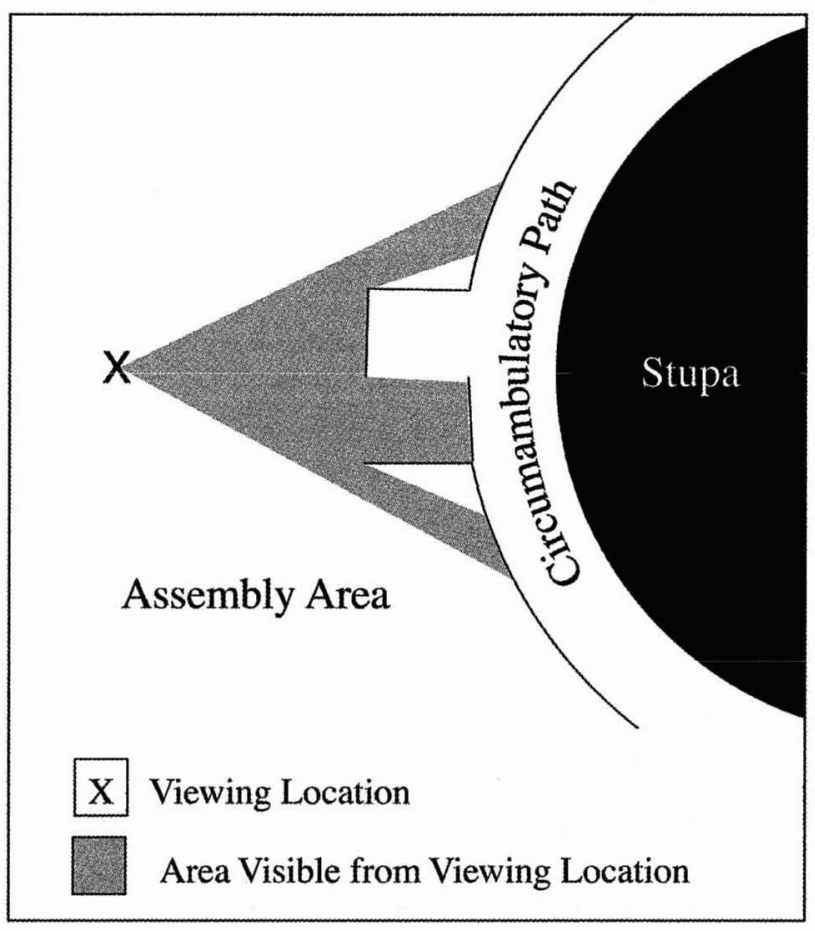

Fig. 5. Schematic diagram of gateways at an open-air stupa complex, showing sightlines.

forced by evidence from some reliefs at Bharhut and Sanchi depicting musicians, dancers, and other individuals in the assembly areas surrounding stupas (see Fig. 7). Sastri's (1966) claim that early Buddhist ritual had an important ecstatic component concords with the large arenas in which communal worship occurred at open-air stupas. The courtyard areas would have allowed for interaction, celebration, and worship. Given this level of activity in the assembly area, the need for the railings to define a segregated circumambulatory path becomes more critical.

The hall form of presentation in the rock-cut stupas implies more corporate or directed worship. Brown's (1965) description of abbots teaching from wooden thrones at the base of stupas in modern Tibet and Nepal serves to illustrate this point. As discussed earlier, the hall form fosters corporate worship by emphasizing the object of worship and ritual mediators while deemphasizing fellow audience members. In all of the rock-cut stupas the dome is located at one end of the hall. This placement has the effect of forcing all audience members to face the same direction, allowing ritual specialists to place themselves between the audience and the stupa. The use of the hall form of presentation in rock-cut stupas betrays an emphasis on more formalized, corporate worship.

Using proximity of the different worship spaces to the stupa as a measure of their relative importance allows for the different forms of worship in the two types of stupa complexes to be ranked. All of the rock-cut stupa complexes place the circumambulatory path in a secondary position to the stupa. In rock-cut stupas, the assembly hall has the most direct access to the dome. This relationship is reversed at open-air stupa complexes. While the assembly area is far larger, the 


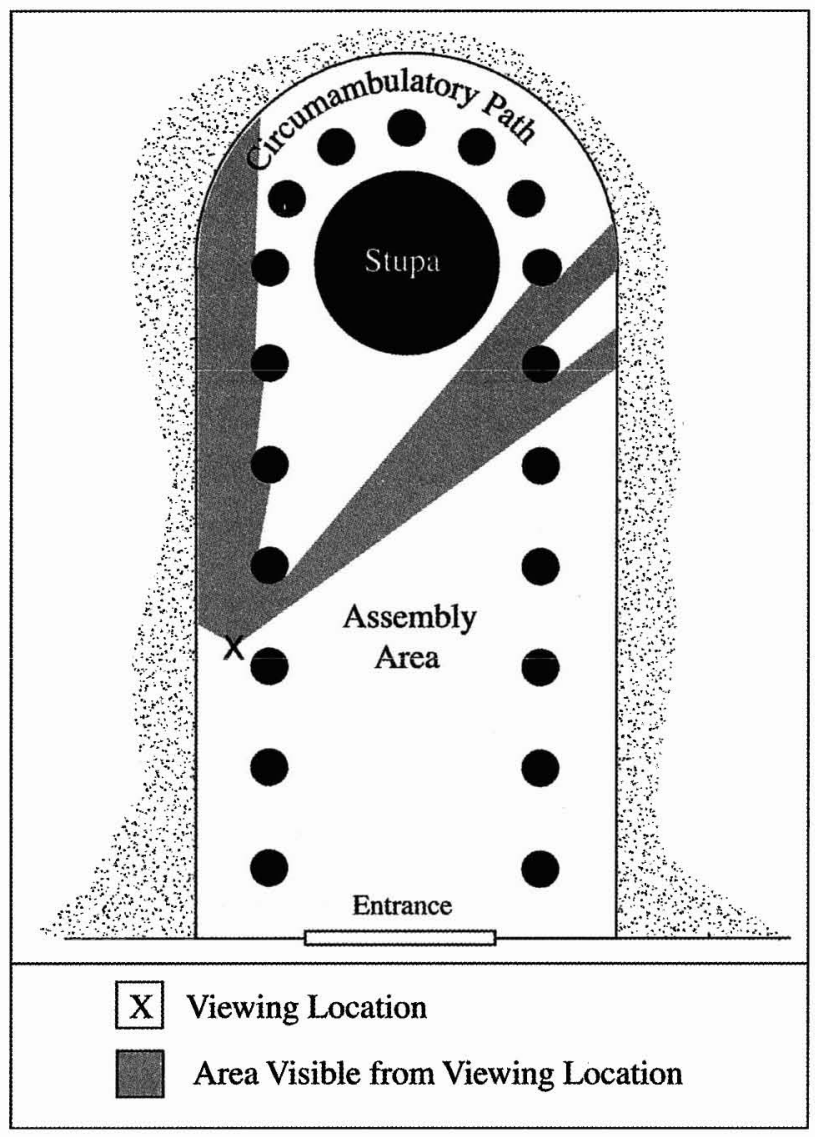

Fig. 6. Schematic diagram of rock-cut stupa complex, showing sightlines.

circumambulatory path lies between the assembly area and the stupa. While it is tempting to justify this difference in terms of sightlines, this does not fully explain the differences. All of the domes in the rock-cut temples are sufficiently elevated to allow for direct circumambulation and small railings. If not for the position of the dome and columns, the same presentational systems could be used in rock-cut stupas as in the open-air stupas. The placement of the path in a secondary position in rock-cut temples was a decision based on religious priorities, not architectural necessities. At open-air stupas, individual worship was emphasized over communal ritual. In rock-cut stupas, individual worship was deemphasized at the expense of corporate worship.

Together these analyses suggest some important differences between open-air and rock-cut stupas during the period from the first century B.C. through second century A.D. Ritual at open-air stupa complexes was either communal or individual, with an architectural emphasis on the latter. The architectural forms of rockcut stupa complexes deemphasized individual worship and emphasized corporate worship. When the differences in the audience of these two types of stupa complex are brought into the analysis, the different expectations and practices of worship between the clergy and laity can be investigated. 


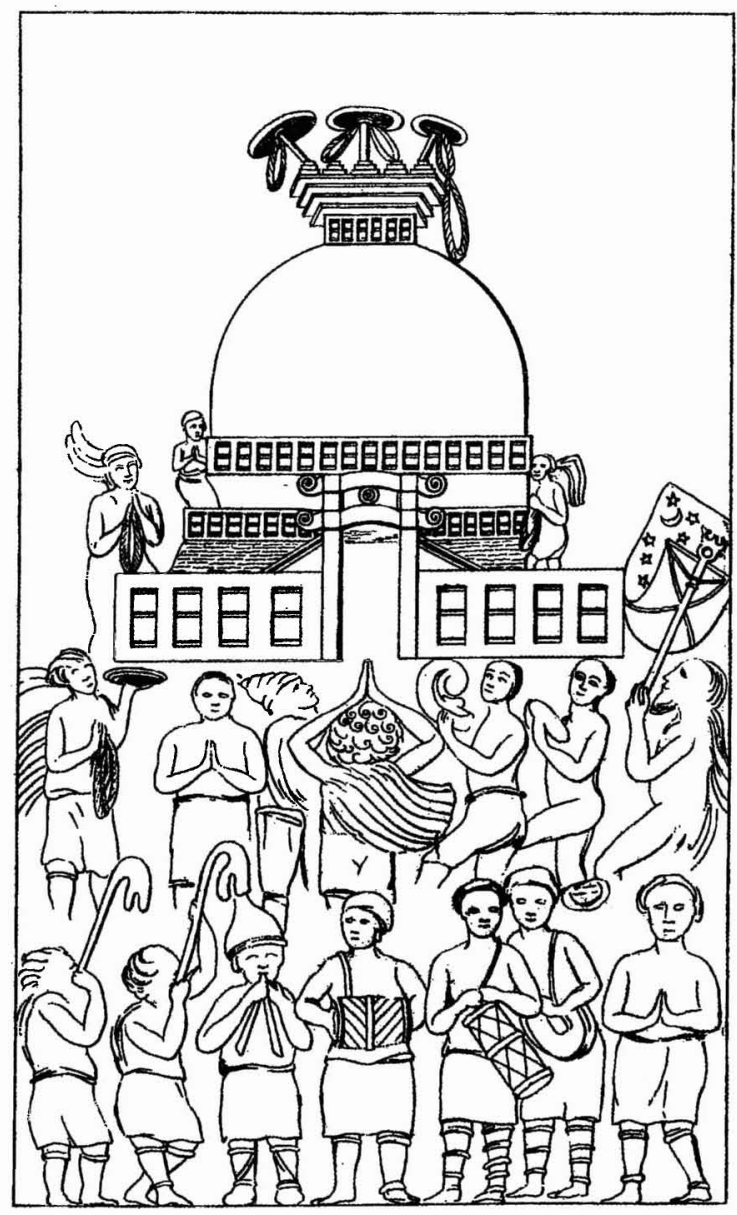

Fig. 7. A relief from Sanchi depicting assembly area activities and worship (from Cunningham 1854: pl. 8).

\section{DISCUSSION}

As presented earlier, the ubiquitous association of stupas with almost all monasteries suggests that the people who designed and controlled them were monks and nuns (Schopen 1997). In rock-cut stupas, the audience was also clerical. In open-air stupas, the audience was a combination of both the clergy and laity, with the latter most likely comprising the majority. Presentational forms are the result of a negotiation between the people who design and build a structure and the audience that is expected to frequent and support that structure. Since the clergy controlled both forms of stupa complexes, the differences between the presentational forms of open-air and rock-cut stupa complexes are the product of the different audiences that frequented them. Thus, the differences in presentational form can be attributed to the different expectations of worship among monastic and lay audiences.

Using the layout and forms of presentation in rock-cut stupa complexes as indicators of monastic expectations of worship, several conclusions can be drawn. First, the hall form of the assembly area indicates that the clergy favored a form of ritual that elevated certain individuals into roles as ritual mediators. Second, using 
proximity to the stupa as a measure of relative importance of different worship spaces, the clergy saw corporate worship in the assembly area as more important than individual worship in the circumambulatory path. Since the circumambulatory path was the more meditative and solitary form of ritual, it seems that monks and nuns were less interested in individual stupa ritual than in corporate, directed worship. The clergy also worshiped the Buddha symbolically, as shown by the lack of relics within many monastic stupas.

In contrast, the form of worship at open-air pilgrimage stupas can be used to address the expectations of the laity. The laity privileged more individualized, meditative worship within the circumambulatory path over group worship practiced in an assembly area, which had less direct contact with the stupa. Even the form of group worship was different. The arena format of the assembly area fostered communal ritual, deemphasizing the potential for ritual specialists acting as mediators between the laity and the Buddha. This designation of the arena as a communal space is reinforced by the presence of numerous, haphazardly placed 'votive' stupas containing the remains of devout Buddhists (Schopen 1997:118). The disorder of their arrangement suggests that no organizing authority had the responsibility of governing the assembly area in open-air stupa complexes. Finally, the stupa in open-air complexes always contained a relic, suggesting that the laity did not accept the worship of a symbolic representation of the Buddha in the form of the stupa. In sum, the laity preferred to worship the Buddha directly, without the imposition of a ritual specialist, in both the circumambulatory path and assembly area. In fact, ritual mediation was effectively limited by the presentational forms of open-air stupa complexes.

\section{CONCLUSION}

These analyses have interesting implications for the value of the concepts of social solidarity and the routinization of charisma as proposed by Durkheim and Weber respectively. Weber $(1958,1978)$ used the "routinization of charisma" to explain how authority associated with a charismatic leader is perpetuated. During their lives, charismatic leaders, such as the Buddha, operate beyond the normative practices of everyday life creating relationships that are "strictly personal" (Weber 1978:246). Such relationships cannot be maintained after the death of the charismatic leader. If the community is to persist, the radical social movement must be reintegrated into broader social traditions from which it diverged. This, of course, necessitates changes within the community itself, as well as modifications to the social order from which it originally emerged. For Weber, such change entailed the transferal of the authority of charisma to a new person, or group of people. Given that the original had often challenged an existing social order, the "routinization of charisma" was most often characterized by the development and imposition of a new power structure, often remarkably similar to that which existed before. It is here that this analysis extends beyond, and diverges from Weber.

The act of transferring the authority of a charismatic leader cannot be assumed to be simple, nor uncontested. Different groups of followers inevitably have different attitudes toward how the community should be perpetuated. Techniques to overcome resistance, and the format in which resistance is practiced, become part of the process of routinization. Through the specific manipulation of ritual 
symbols and space, the monks attempted to assert their privileged relationship to the Buddha. In the period addressed in this paper, this authority was not yet fully recognized by the laity. The laity continued to perpetuate a direct form of worship with the Buddha himself, through the worship of his relics. The monks, on the other hand, had succeeded in transferring the authority of the Buddha, at least in their own eyes. Their worship in monastic communities, as shown by their architectural layout, acknowledged that certain members of the community were recipients of greater authority than others.

Durkheim (1915 [1995]) viewed religion and ritual as sources of social cohesion or "social solidarity" that helped reduce the friction between individual members of society. This paper suggests that the form in which solidarity is perpetuated is contested by the same divisions it attempts to deny. The form of solidarity employed in the monasteries was based upon common identification with a ritual specialist, while that of Buddhist laypeople was based upon communal group identification, which resisted the hierarchical ordering of worshipers. Both systems served to integrate a larger Buddhist community within an individualistic religious tradition, but each had important implications for the power relations between community members. Within the Buddhist community, the laity and clergy each favored different forms of social solidarity, as each group sought the greater accumulation of power or autonomy. During the early historic period, this tension remained unresolved. Social solidarity within each group was achieved, while a common solidarity between them was not.

These modifications to Durkheim and Weber are heavily influenced by the emphases on power and resistance that have percolated through the anthropological and archaeological literature in the last twenty years (e.g., Foucault 1977; Markus 1993; Miller et al. 1989; Zukin 1991). Following these developments, I reject a concept of society as a unitary phenomenon with a ubiquitous presence of social hierarchies. Rather, a greater emphasis is placed on the competing interests of different social groups, and the traces these factions (Brumfiel 1992, 1995; Brumfiel and Fox 1994; Crumley 1987, 1995) leave on the architectural remains that survive for modern archaeological study. That said, the focus of this paper is not an explication of the concepts of power, agency, faction, or resistance. These concepts are explored well within a wide variety of recent, more theoretically oriented, articles and books (Barrett 2001; Dobres and Robb 2000; Ehrenreich et al. 1995; Robb 1999). Rather, this paper investigates the specific spatial manipulations of ritual architecture to identify the social and ideological tensions that existed between two major social groups within early Buddhism.

One final line of research that should be investigated concerns possible differences in worship styles among different subsets of the laity. Within this analysis, the laity has been presented as having a uniform attitude toward worship. However, frequencies of donation to open-air and rock-cut stupa complexes by different occupational groups suggest that diverse social groups may have had distinctive expectations of worship. In particular, it seems likely that the higher class Buddhists, from which it can be assumed most of the clergy were drawn, disproportionately supported monastic stupa complexes. If this is the case, ritual and architectural differences discussed in this paper may also be indicative of the differing goals of higher and lower class Buddhists in conjunction with the monk/ laity distinction investigated here. 
This analysis illustrates how an investigation of the manner in which objects are presented can inform upon religious ideology. In this case, the forms of presentation have illuminated two underlying tensions in early Buddhism. First, the organization of stupa complexes into two distinct ritual spaces demonstrates two different solutions to overcoming the problem of maintaining group cohesion within a highly individualistic religious tradition. Second, by comparing the methods employed in monastic and pilgrimage sites, this analysis has shown differing attitudes to worship held by monks and laity. It appears that it was the laity, not the clergy, who favored meditative ritual. Further, the laity was less interested in the elevation of ritual specialists. This is in many ways the exact opposite of the picture found in the Buddhist religious texts. This research has also reexamined the concepts of "social solidarity" and the "routinization of charisma." While the concepts have been modified to accommodate more complex understandings of social organization, both continue to have utility in modern research. As a whole, this study is intended to illustrate the possibilities of architectural analysis in addressing both ritual and social order in past societies. Examining how people wish to be seen can tell a great deal about who they are.

\section{ACKNOWLEDGMENTS}

Thanks go first to Carla Sinopoli. Her comments on each draft and incarnation of this paper have greatly improved it. I also thank Tom Trautman, Joyce Marcus, Henry Wright, Jeff Parsons, Norm Yoffee, Monica Smith, Julia Shaw, Donald Lopez, Himanshu Ray, Miriam Stark, Heather Miller, and several anonymous reviewers for comments on drafts of this paper. Earlier versions of this paper were presented at the 25th annual conference on South Asia (Madison, Wisconsin, 1996) and the American Anthropological Association meetings (Philadelphia, Pennsylvania, 1998).

\section{REFERENCES CITED}

BARNeS, G. L.

1995 An introduction to Buddhist archaeology. World Archaeology $27: 165-182$.

BARRETt, J. C.

2001 Agency, the duality of structure, and the problem of the archaeological record, in Archaeological Theory Today: 141-161, ed. I. Hodder. London: Polity.

BARUA, B.

1979 Barhut: Parts 1, 2, and 3. Varanasi: Indological Book House.

BASHAM, A. L.

1967 The Wonder That Was India. Calcutta: Rupa and Co.

1989 The Origins and Development of Classical Hinduism. Delhi: Oxford University Press.

BECHERT, H., ED.

1995 When Did the Buddha Live? The Controversy on the Dating of the Historical Buddha. Delhi: Sri Satguru Publications.

BeLL, C.

1997 Ritual: Perspectives and Dimensions. Oxford: Oxford University Press.

Bourdieu, $\mathrm{P}$.

1973 The Berber House, in Rules and Meanings: 98-110, ed. M. Douglas. Middlesex: Penguin Books.

1977 An Outline of a Theory of Practice. Cambridge: Cambridge University Press. 
Bradley, R.

1998 The Significance of Monuments: On the Shaping of Human Experience in Neolithic and Bronze Age Europe. New York: Routledge.

Bradley, R., ED.

1990 Monuments and the Monumental. World Archaeology 22.

Brown, P.

1965 Indian Architecture: The Buddhist and Hindu Periods. Bombay: D. B. Taraporevala Sons and Co.

Brumfiel, E. M.

1992 Breaking and entering the ecosystem: Gender, class, and faction steal the show. American Anthropologist $94: 551-567$.

1995 Heterarchy and the analysis of complex society: Comments, in Heterarchy and the Analysis of Complex Society: 125-131, ed R. Ehrenreich, C. Crumley, and J. Levy. Washington, D.C.: American Anthropological Association.

Brumfiel, E. M., AND J. W. Fox, eds.

1994 Factional Competition and Political Development in the New World. Cambridge: Cambridge University Press.

Carmichael, D., J. Hubert, B. Reeves, and A. Schanche, eds.

1994 Sacred Sites, Sacred Places. London: Routledge.

Carrithers, $M$.

1983 The Forest Monks of Sri Lanka: An Anthropological and Historical Study. Delhi: Oxford University Press.

Chakrabarti, D. K.

1995 Buddhist sites across South Asia as influenced by political and economic forces. World Archaeology 27:185-202.

2001 The archaeology of Hinduism, in Archaeology and World Religion: 33-60, ed. T. Insoll. New York: Routledge.

Coningham, R.

1995 Monks, caves and kings: A reassessment of the nature of early Buddhism in Sri Lanka. World Archaeology $27: 222-242$.

1998 Buddhism 'rematerialized' and the archaeology of Gautama Buddha. Cambridge Archaeological Journal 8:121-126.

2001 The archaeology of Buddhism, in Archaeology and World Religion: 61-95, ed. T. Insoll. London: Routledge.

CoOmaraswamy, A. K.

1927 History of Indian and Indonesian Arts. New York: E. Weyhe.

Crumley, C.

1987 A dialectical critique of hierarchy, in Power Relations in State Formation: 155-170, ed. T. Patterson and C. Gailey. Washington, D.C.: American Anthropological Association.

1995 Heterarchy and the analysis of complex society, in Heterarchy and the Analysis of Complex Society: 125-131, ed. R. Ehrenreich, C. Crumley, and J. Levy. Washington, D.C.: American Anthropological Association.

Cunningham, A.

1854 The Bhilsa Topes or Buddhist Monuments of Central India. New Delhi: Munshiram [1997] Manoharlal.

1876 The Stupa of Bharhut: A Buddhist Monument Ornamented with Numerous Sculptures. Varanasi:

[1962] Indological Book House.

DAvids, T.W.R.

1910 Buddhism: Being a Sketch of the Life of Gautama, The Buddha. London: Society for Promoting Christian Knowledge.

DEHEJIA, V.

1972 Early Buddhist Rock Temples. Ithaca: Cornell University Press.

DE JONG, JAN WILLEM

1987 A Brief History of Buddhist Studies in Europe and America. Delhi: Sri Satguru Publications. 
Dobres, M., AND J. E. RobB, EDs.

2000 Agency in Archaeology. London: Routledge.

Dundas, P.

1992 The Jains. New York: Routledge.

DURKHEIM, E.

1915 The Elementary Forms of Religious Life. New York: Free Press.

[1995]

Ehrenreich, R., C. Crumley, and J. Levy, eds.

1995 Heterarchy and the Analysis of Complex Societies. Washington, D.C.: American Anthropological Association.

Fergusson, J., AND J. Burgess

1880 The Cave Temples of India. New Delhi: Munshiram Manoharlal Publishers Pvt. Ltd. [1988]

Foucault, Michel

1977 Discipline and Punish: The Birth of the Prison. New York: Vintage Books.

Garwood, P., D. Jennings, R. Skeates, and J. Toms

1991 The Sacred and Profane: Proceedings of a Conference on Archaeology, Ritual and Religion. Oxford, 1989. Oxford: Oxford University Committee for Archaeology.

GHosh, A.

1968 Two early Brahmi inscriptions from Ajanta. Epigraphia Indica 37.

GIDDENS, A.

1984 The Constitution of Society: Outline of a Theory of Structuration. London: Polity.

HeItzman, J.

1984 Early Buddhism: Trade and empire, in Studies in the Archaeology and Paleoanthropology of South Asia: 21-37, ed. K.A.R. Kennedy and G. Possehl. New Delhi: Oxford University Press.

Hullier, B., AND J. Hanson

1984 The Social Logic of Space. Cambridge: Cambridge University Press.

IRWIN, J.

1980 The axial symbolism of the early stupa: An exegesis, in The Stupa: Its Religious, Historical, and Architectural Significance: 12-38, ed. A. L. Dollapiccola and S. V. Lallemant. Wiesbaden: Franze Steiner Verlag.

KENT, S., ED.

1990 Domestic Architecture and the Use of Space: An Interdisciplinary Cross-Cultural Study. Cambridge: Cambridge University Press.

KowALSKI, J. K., ED.

1999 Mesoamerican Architecture as a Cultural Symbol. Oxford: Oxford University Press.

LAHIRI, N.

1992 The Archaeology of Indian Trade Routes (up to c. 200 B.c.). Delhi: Oxford University Press.

LAmotTe, E.

1988 History of Indian Buddhism from the Origins to the Saka Era. Louvain-la-Nueve: Institute Orientaliste, Universite de Louvain.

LOPEZ, D. S.

1995 Introduction, in Buddhism in Practice: 3-36, ed. D. S. Lopez. Princeton: Princeton University Press.

LUDERS, $\mathrm{H}$.

1912 A list of Brahmi inscriptions. Epigraphia Indica 10.

Markus, T. A.

1993 Buildings and Power. New York: Routledge.

Marshall, J.

1951 Taxila: An Illustrated Account of Archaeological Excavations Carried out at Taxila under the

[1975] Orders of the Government of India Between the Years 1913 and 1934. Delhi: Motilal Banarsidass. 
Marshall, J., AND A. Foucher

1983 The Monuments of Sanchi. Delhi: Swati Publications.

Miller, D., M. Rowlands, and C. Tilley, eds.

1989 Domination and Resistance. London: Unwin Hyman.

Mitra, D.

1965 Sanchi. New Delhi: Archaeological Survey of India.

1971 Buddhist Monuments. Calcutta: Sahitya Samsad.

MoOre, J. D.

1996 Architecture and Power in the Ancient Andes. Cambridge: Cambridge University Press.

MORRISON, K.

1995 Trade, urbanism, and agricultural expansion: Buddhist monastic institutions and the state in early historic western Deccan. World Archaeology 27:203-221.

Muni, Bharata

1986 Natyasastra: English Translation with Critical Notes. Translated by Adya Rangacharga, Bangalor: IBH Prakashana.

Nagaraju, S.

1981 Buddhist Architecture of Western India. Delhi: Agam Kala Prakashan.

PAyne, D. R.

1993 Scenographic Imagination. Carbondale: Southern Illinois University Press.

Pearson, M. P., and C. Richards, eds.

1994 Architecture and Order: Approaches to Social Space. London: Routledge.

RAPOPORT, A.

1982 The Meaning of the Built-Environment. Beverly Hills: Sage Publications.

RAY, H. P.

1986 Monastery and Guild: Commerce under the Satavahanas. Delhi: Oxford University Press.

1989 Early historical trade: An overview. The Indian Economic and Social History Review 26:437457.

1994 Kanheri: The archaeology of an early Buddhist pilgrimage center in western India. World Archaeology 26:35-46.

RoвB, J. E., ED.

1999 Material Symbols: Culture and Economy in Prehistory. Carbondale: Center for Archaeological Investigations, Southern Illinois University.

SARKAR, H.

1966 Studies in Early Buddhist Architecture of India. New Delhi: Munshiram Manoharlal.

SAstri, N.

1966 The Satavahanas and their successors, in A History of South India: From Prehistoric Times to the Fall of Vijayanagar. Delhi: Oxford University Press.

SCHOPEN, G.

1997 Bones, Stones, and Buddhist Monks: Collected Papers on the Archaeology, Epigraphy, and Texts of Monastic Buddhism in India. Honolulu: University of Hawai'i Press.

Sharma, H. V.

1987 The Theatres of the Buddhists. Delhi: Rajalakshmi Publisher.

SHAw, J.

1999 Buddhist landscapes and monastic planning: The elements of intervisibility, surveillance and the protection of relics, in Case Studies in Archaeology and World Religion: 5-17, ed. T. Insoll. Oxford: Archaeopress.

2000 Sanchi and its archaeological landscape: Buddhist monasteries, settlements and irrigation works in central India. Antiquity $74: 775-776$.

SMith, A., AND A. Brookes, eds.

2001 Holy Ground: Theoretical Issues Relating to Landscape and Material Culture of Ritual Space Objects. Oxford: Archaeopress.

SNODgrass, A.

1992 The Symbolism of the Stupa. Delhi: Motilal Banarsidass. 
SPINK, W. M.

1991 The Archaeology of Ajanta with Tables. Ars Orientalis $21: 67-94$.

STRONG, J. S.

1983 The Legend of King Asoka. Princeton: Princeton University Press.

1994 Images of Asoka: Some Indian and Sri Lankan Legends and their Development, in King Asoka and Buddhism: Historical and Literary Studies: 99-126, ed. A. Seneviratne. Kandy: Buddhist Publication Society.

Tамвiah, S. J.

1969 Animals are good to think and good to prohibit. Ethnology 8:424-459.

THAPAR, R.

1966 A History of India, vol. 1. London: Penguin Books.

1997 Asoka and the Decline of the Mauryas. Delhi: Oxford University Press.

Tilley, C.

1994 A Phenomenology of Landscape. Oxford: Berg Publishers.

TrainOR, K.

1997 Relics, Ritual, and Representation: Rematerializing the Sri Lankan Theravada Tradition. Cambridge: Cambridge University Press.

WEBER, M.

1958 The Protestant Ethic and the Spirit of Capitalism. New York: Scribner.

1978 The routinization of charisma, in Economy and Society: 246-254, eds. Guenther Roth and Claus Wittich. Berkeley: University of California Press.

ZuKIN, S.

1991 Landscapes of Power: From Detroit to Disney World. Berkeley: University of California Press.

\section{ABSTRACT}

The physical organization and layout of Buddhist reliquary mounds, stupas, provides a window into the forms of ritual practiced by Buddhists in the first few centuries B.C. through the end of the second century A.D. Specifically, the manner in which stupas were architecturally presented informs upon the differences in ritual presentation by the clergy and the laity. Attempts by the Buddhist clergy to direct worship and establish a privileged position in regard to the Buddha were resisted by the laity; in contrast, the laity attempted to preserve the egalitarian aspects of Buddhism. Traces of the laity's resistance can be identified in the architectural layouts of ritual spaces of the early Buddhists. The organization of ritual within stupa complexes also illustrates the methods used by early Buddhists to foster group cohesion within a highly individualistic religious tradition. KEYwORDs: Buddhism, ritual, architecture, presentation, stupas. 